https://doi.org/10.18485/iipe_euchanges.2021.ch17

\title{
EAST-CENTRAL EUROPE AND THE TRANSFORMATION OF GLOBAL IDEOLOGY
}

\begin{abstract}
Stephen BASKERVILLE ${ }^{1}$
Abstract: Radical ideologies originated in Europe, but have spread worldwide. Since radical religious movements emerged in the late Middle Ages and the Reformation, ideologies have dominated and defined modern European history. Today's most salient ideologies differ from the past. While extreme nationalism and socialism dominated the nineteenthtwentieth centuries, extremism today comes from outside Europe, mostly based on religion. This is reminiscent of Europe's less recent past. Religious ideology and connected ideological innovations introduce complex dynamics into European politics. Islamism has provoked European controversies over immigration and national identity. But more, a new polarity has emerged, with Russia's bid to lead global Christianity against Western secularism. This makes East-West polarisation cultural as well as political. External religious ideologies also intensify existing European controversies over family-sexuality. Central and Eastern Europe (CEE), though largely free of radical ideology today, is again caught between major powers and ideologies. A global ideological polarity running along lines of religion and connected issues makes CEE once again pivotal, given the importance of religious values there. While these values are traditionalist and not radical, religious radicalism from outside creates tensions between CEE and its European Union (EU) partners. All this gives CEE importance above its size, potentially making it a broker between East and West (or even West and South). With Hungary and Poland pushing back against some western and EU innovations, the internal tensions and ambivalences in CEE countries can have repercussions for the larger alignments both within Europe and externally. Expanding the EU with new members from Southeastern and Eastern Europe could further fuel this dynamic.

Keywords: ideology, religious radicalism, Central and Eastern Europe, European Union, Islamism, sexual politics, Puritanism.
\end{abstract}

${ }^{1}$ Research Fellow, Inter-American Institute, E-mail: skbaskerville@gmail.com 
It is humbling to write on ideologies in East-Central Europe. Hardly can there be a region that has suffered more from the ravages of ideology. Richard Weaver's phrase, 'ideas have consequences,' is hardly one that must be pleaded in this part of Europe.

But I want to discuss newer ideologies than what most of us are accustomed to studying because ideology today is taking new forms. Like generals condemned to fight the previous war, I fear we are still responding to the ideologies of yesteryear rather than those confronting us today.

I will suggest that recent ideological realignments worldwide are exerting pressure on the internal politics of East-Central Europe (CEE), a region long recognized to be pivotal geopolitically (Mackinder, 1904). This bears some similarities to the twentieth century when the region was polarised, first by totalitarian ideologies and then by the Cold War. But the impact of today's ideologies is more complex. Though CEE itself is largely free of radical ideology, its relationship with western political structures, especially the European Union (EU), is being tested by new ideological pressures, largely external, though some are also felt in the internal politics of individual states. These tensions are well known, and I will not describe them here. My aim is to elucidate the larger ideological context in which CEE now finds itself.

\section{THE APPEARANCE OF IDEOLOGY}

The radical ideologies of the last century politicised two broad areas of life: fascism politicised ethnicity or, in its extreme form, race; and communism politicised economic and social relations. But while today's ideologies have their origins in those of the past, they are different. After the Second World War, scholars like Hannah Arendt, Carl Friedrich, and Zbigniew Brzezinski defined and debated these totalitarian ideologies. A notable feature of this scholarship was a counterintuitive emphasis on the affinities between ideologies whose content seemed diametrically opposed - from the far right to the far left. (Mussolini's mutation from socialist to fascist, or the Hitler-Stalin pact are the most-cited manifestations, but there are others.) This kind of scholarship has had something of a renaissance following the collapse of Communism in 1989. ${ }^{2}$

${ }^{2}$ Tismaneanu, 2014 represents a renewal of this style of scholarship. 
I will not re-engage with those debates from the past except to say that when I speak of ideology, I emphatically do not accept the loose sense often used today to mean any form of political or other belief so that everyone is said to subscribe to some ideology or another. This sleight-of-hand serves certain current political, indeed ideological, agendas, specifically those that aim to politicise everything.

Rather, radical ideologies are a historically specific phenomenon. They did not exist in ancient or early medieval politics. They emerged in early modern or late medieval Europe at the earliest (Walzer, 1965). The point of my argument is that radical ideologies have changed in form and content. Since the beginning of modern history, we have seen ideologies in various forms. Broadly categorised:

- religious $\left(16^{\text {th }}-17^{\text {th }}\right.$ centuries $)$

- republican $\left(18^{\text {th }}\right.$-early $19^{\text {th }}$ century)

- nationalist $\left(19^{\text {th }}-20^{\text {th }}\right)$

- socialist (late $19^{\text {th }}-20^{\text {th }}$ )

- more extreme and totalitarian forms of these that are Fascist, Nazi, and Communist $\left(20^{\text {th }}\right)$

Recently, some have coined the term 'Islam-ist' and 'Islam-ism' to refer to politicised and terrorist forms of Islam in our own time - Islam as a political ideology (Hansen\&Kainz, 2007).

The advent of Islamism has changed the game and confused the terms of debate significantly, and it did so by bringing religion back into the equation. Conventional wisdom dates the appearance of ideological politics to the secularism of the French Revolution. But this is arbitrary and arises because many scholars are, for different reasons, uncomfortable confronting the issue of religion and have formed tacit collusion between the left and right to avoid it. ${ }^{3}$

For it is plausibly argued that modern political ideologies originated in the radical religious movements of the late Middle Ages. ${ }^{4}$ While movements like the Cathars and Bogomils lacked the overtly political aspirations that would

${ }^{3}$ The reticence of scholars to accept religiously inspired revolutions as real revolutions is discussed in Walzer, 1970, and Baskerville, 2004.

${ }^{4}$ For example, Cohn, 1970. Philosopher Eric Voegelin (1998) viewed secular political ideologies as throwbacks to early Christian heresies. 
qualify them as true modern ideologies, this changed with the better-organized movements surrounding the Protestant Reformation (Walzer, 1965).

The first radical religious movement to become explicitly politicised was in East-Central Europe: the Hussites in Bohemia. The Czech historian František Palacký wrote, 'The Hussite war is the first war in the world's history that was fought, not for material interests but...for ideas. ${ }^{5}$

A similar logic suggests that ideological religion originated in the Anglophone world: by Puritan radicals who took inspiration from Jan Hus and Hussitism but who were able, for various reasons (like the printing press), to apply such ideas on a much larger scale. There was, after all, at least one major modern revolution before the French, and that occurred in England. ${ }^{6}$

This plausible argument has not been pursued by students of ideology (and it is not explored by the many students of 'religious violence' today, e.g., Juergensmeyer\&Kitts, 2011, and Juergensmeyer, Kitts\&Jerryson, 2013), but the implications are enormous. For if you identify the English Revolution as the first modern revolution, then you might have to include the American Revolution, which was driven by similar principles. To trace modern ideological politics to the religious conflicts of the seventeenth century and the Puritans is to place them at the inception of two of the most important nation-states of modern history (and ironically, two peoples who have prided themselves on their un-ideological politics): modern England and the United States.

\section{THE RE-EMERGENCE OF RADICAL RELIGION}

Those who seek the origins of political radicalism in religious radicalism seem vindicated by the re-emergence of radical religion in our own time. The growth of radical Islam lends plausibility to the argument that ideologies were religious in origin. Islamist radicalism seems to indicate that we have come full circle, returning to the original religious source of radical politics.

\footnotetext{
${ }^{5}$ Quoted in Count Lutzow, 1909, p. 335. See also Baskerville, 2004.

${ }^{6}$ One of the most important books of post-war New Left scholarship - ignored by both left and right - is Walzer, 1965. Rachik (2009, pp. 351-353) partially bases his argument on Walzer's. A more substantive attempt to assess it is Baskerville, 2018b.
} 
Some problems arise with this line of argument, problems with how we understand history or perhaps manipulate it.

First, as noted, some want to label all political beliefs as ideologies. Thus, for example, Christianity itself is labelled, with great imprecision, as an 'ideology.' Certainly, particular manifestations of Christianity can be described as ideological: those with political aspirations and methods such as, again, the revolutionary, theocratic wings of Hussitism or Puritanism. The validity of today's similar distinction between Islam (a religion) and Islamism (a political ideology) must be assessed by scholars from those fields.

Some today also want to simply equate all forms of religious radicalism - and even all religion - with Islamist terrorism. ${ }^{7}$ A fairly clear ploy is operating here: It is an ahistorical and therefore a false effort to condemn all dissenting religion, if not all religion (Cavanaugh, 2009).

It ignores the fact that the Hussites and Puritans never advocated or engaged in assassination or terror, let alone terrorism; neither did they romanticise martyrdom, as do today's jihadists. Also, while past religious ideologies provoked intense political violence and other atrocities, subsequent secular political ideologies have perpetrated vastly more.

But a deeper, more profound understanding of radical Islam demands our attention - one that indeed tells us something about ourselves.

First, Islamism is not simply a throwback to 'medieval' religion. It is an eclectic hodgepodge of ideas, both religious and secular. Some, of course, are taken from the Quran and other Islamic sources. But many are borrowed directly from modern Western secular ideologies themselves - including socialism, communism, and fascism (Ulph, 2012; Hansen\&Kainz, 2007).

This is apparent in the most sophisticated manifestation of Islamist radicalism so far, produced in one of the richest political cultures in the Islamic world: the Iranian Revolution of 1979. This manifestation of Islamist ideology bears a comparison with the 'great' revolutions of the West: England, France, Russia. Whatever one's opinion of the Iranian Revolution, it cannot be characterised as obscurantist 'fundamentalism.' It is a complex mixture of ideas borrowed (as revolutionary ideas always are) from others: nationalism, liberalism, socialism, and - a paradox to which I will return even feminism (Ziemke, 2000).

7 The huge recent literature on 'religious violence" attests to this: e.g., Jeurgensmeyer \&Kitts, 2011; Juergensmeyer, Kitts\&Jerryson, 2013. 
To understand Islamist radicalism today, we must understand why it has arisen. (And one might include other manifestations of radical religion, such as Hindutva or radicalized Buddhism). I hope it can tell us something more important about our own ideological past and present - both the religious episodes and the secular ones.

Islamism has arisen in part from the failure of secular ideologies to deliver on their promises, especially in the global South. Radicals turn to religious ideologies because the secular ideologies - modified versions of their predecessors developed here in Europe - have failed, much as Communism failed in Europe. The post-war secular ideologies to which many intellectuals in the global South looked for 'national liberation' involved hybrids of nationalism and socialism: pan-Arabism and pan-Africanism, most obviously. As in Europe, they brought neither freedom nor prosperity but mostly economic stagnation, political instability, and repression.

It is hardly surprising that some radical intellectuals turned to seemingly more spiritual ideas for their liberation, even if the beliefs they adopted were sometimes little more than secular ideologies covered over with a veneer of spirituality. Islamism (Hindutva, political Buddhism, etc.) is the logical alternative to the failure of the same twin ideologies that failed in Europe: extreme nationalism and socialism. ${ }^{8}$

Why? I could suggest clichés about the centrality of the spiritual dimension of human life. Man is a religious animal - animal religiosum ${ }^{9}$ or homo religiosus in the phrase of Romanian philosopher Mircea Eliade.

But some argue that the recent alternative movements are really political ideologies with a religious covering. 'While steeped in Islamic myth and forms, the events of 1979 represented first and foremost a political revolution,' writes Caroline Ziemke.

Khomeini's revolutionary role models were secular and, for the most part, Western. During the revolution and since, revolutionary political goals have always taken precedence over religious goals. ... Iranian law contains many non-Islamic concepts: legal (if not yet actual) equality between the sexes concerning property, employment, and family rights.... (Ziemke, 2000, pp. 98-99)

\footnotetext{
${ }^{8}$ See Walzer, 2015, though he may not agree with my synopsis.

${ }^{9}$ See also Charnock, 1840, p. 6.
} 
Conversely, again, some argue that even the 'secular' ideologies began as a corruption of religion. And no religious revolt is ever purely religious; social and economic and political grievances are always included in the mix.

So ultimately, there may be no clear distinction between 'religious' and 'secular' extremism. To avoid quibbling about words, we must dig deeper into why these ideologies arise.

One striking feature of Islamism, making it so difficult to analyse and confront, is its promiscuous combination of grievances we in the West often consider inconsistent. As if to vindicate the scholars of totalitarianism who stressed the ironic affinities between Nazism and Communism, today's Islamism combines within itself complaints against the West associated with both the right and left.

This suggests several features of ideologies shared by both religious and secular versions: First, they always express grievances, and they thrive on the most dangerous emotion in politics: resentment (Baskerville 2018b). This helps to distinguish two similar phenomena that are not distinguished often enough: 'the confusion of patriotism (old and traditional) with nationalism (new and democratic)' (Lukacs, 2009). Patriotism is love and loyalty to a country and community. Nationalism always involves some discontent or grievance directed at someone else.

It is also worth noting that the Islamist complaints against both left and right have other features in common: They are both directed at the West, against liberalism, and against middle-class values.

This derives from another critical feature common to all ideologies: Regardless of their professed purposes, they all seek power as their ultimate aim, and they are willing to combine apparently inconsistent and even antithetical ideas and goals - and form improbable alliances with 'strange bedfellows' - in order to acquire power. In other words, they will readily sacrifice their most loudly touted principles. 'Power is the alpha and the omega of contemporary Communism,' observed Yugoslav dissident Milovan Djilas in the 1950s. 'Ideas, philosophical principles, and moral considerations... all can be changed and sacrificed. But not power' (Djilas, 1958, p. 170).

\section{THE NEW PURITANISM}

On the one hand, Islamism continues the complaints of the post-colonial left against Western colonialism-imperialism and capitalism. It also borrows 
heavily from the ideological left and often contains elements of de facto socialism (clear in the current Iranian regime). This explains the otherwise strange affinity the Western left shows toward Islamism and its reluctance to criticise Islamist atrocities. 'It is striking,' remarked Fred Halliday of the 'politically articulated accommodation... between Islamism as a political force and many groups of the left' (Halliday, 2011, p. 77). Even feminism manages to make its peace with radical Islam, as we will see (Hymowitz, 2003).

I want to concentrate on the complaints Islamism seems to share with the right, which have never been placed in their full historical and political context. It involves several grievances, but the most important involves women, the family, and sexuality.

As many scholars have emphasized, this is not a marginal matter. 'The centrality of gender relations in the political ideology of Islam,' in the words of Parvin Paidar, is now widely acknowledged by scholars (Kazemzadeh, 2002, p. 4). Whatever the various resentment fuelling Islamist activism, the Islamist response largely distils down in sexual regulation. Radical Muslims understand that controlling sex and claiming sexual purity translate into political power. 'The issue of women is not marginal,' write Ian Buruma and Avishai Margalit; 'it lies at the heart of Islamic [radicalism]' (Buruma\&Margalit, 2004). The relationship between sexual discipline and political power, at one time well understood in the West (as we shall see), is now largely forgotten in Europe. But Islamists understand it keenly. 'The hejab has been identified by the [Iranian] regime as the very cornerstone of its revolution,' notes Haideh Moghissi. 'It is described as basic to Islamic ideology and...seen by them as denoting deliverance from the yoke of imperialism 'and as representing' a symbol of liberation and resistance to capitalism and of revolutionary aspirations' (Moghissi, 2004, pp. 77-78).

The suggestion ${ }^{10}$ that Western sexual dissipation inflames Muslim hostility and plays into the hands of Islamist radicals cannot be completely dismissed. 'The West is...a society in which the number of illegitimate children approaches and sometimes surpasses the number of children from permitted unions,' declares one radical sheikh, accurately (D'Souza, 2007, p. 153).

At the same time, Islamist militancy is no simple return to traditional family values. It is a fanatical and terrorist ideology that freely borrows from its kindred Western ideologies. The larger point is not the specific demands

${ }^{10}$ D'Souza, 2007, pp. $150,152,153$, provides a popular example. 
of radical Islamists; it is that they seek to control the terms of sexuality and use it to acquire political power. Again, radical Muslims understand something that we in the West at one time also understood but have forgotten: that controlling sexuality and claiming sexual purity translate into secular political empowerment.

This helps explain the otherwise puzzling paradox that, more than any other, inhibits our understanding of radical Islam: If Islamism oppresses women, why does it attract such large numbers of them? 'Many observers have wondered why women in the hundreds of thousands, including educated women, actively supported a movement which appeared to curtail their rights' (Roded, 1999, p. 255). These are consciously dedicated Islamist women, attired decidedly in veils, and often armed. 'Observers have all noted the presence and activism of women in the Islamist movement,' writes Olivier Roy; 'recall the demonstrations of armed and veiled women in Iran' (Roy, 1998, p. 59).

Contrary to the stifling political correctness that distorts Western understanding of this important phenomenon, these women are not coerced into this involvement. They are enthusiastic operatives in a movement that is consciously determined to acquire political power, and they understand very clearly that controlling the terms of sexuality and claiming sexual purity are the most effective means of acquiring it.

\section{THE WEST'S SEXUAL JIHAD}

In this respect, a parallel battle is being fought today in the secular West, and Islamist militants share this preoccupation with elements that now dominate the Western left. For throughout the Western world too, the ideological fault lines have been shifting from economic and social cleavages that drove socialist ideology to grievances that are sexual. Newsweek magazine calls this 'the politics of sex.'11

This is not new. The Western left has had a long history of ambivalence toward sexual freedom. Though Western radical movements have usually contained fringe elements of bohemianism and libertinism, the most successful secular political ideologies have been sexually puritanical. 'Ironically, those countries which rejected religion in the name of

${ }^{11}$ Magazine cover: https://www.thewrap.com/newsweek-avoids-condomsnudity-politics-sex-cover-35368/. 
Communism tended to adopt their own version of sexual puritanism, which often matched those of the religions they assailed,' Dennis Altman observes. The most effective radical agitators have sought to limit sexual license. A major achievement of Bolshevism, for example, was to discipline the cadres' 'infantile' bohemianism by channelling the libido into party activity. 'Drown your sexual energy in public work,' urged Nicolai Semashko, the first People's Commissar for Health. 'If you want to solve the sexual problem, be a public worker.' Likewise, Lenin himself: 'The revolution...cannot tolerate orgiastic conditions, such as are normal for the decadent,' he insisted.

Dissoluteness in sexual life is bourgeois, is a phenomenon of decay. The proletariat... does not need intoxication as a narcotic or a stimulus. Intoxication as little by sexual exaggeration as by alcohol. ... Self-control, self-discipline is not slavery, not even in love. ${ }^{12}$ (Altman, 2002, p. 6; Eley, 2002, p. 188; Zetkin, 1934.)

When liberal bohemianism crept back into early Soviet family policy in the form of easy divorce laws, it caused social havoc and had to be abandoned (The Russian Effort to Abolish Marriage, 1926).

The recent Western left has embraced sexuality with (so to speak) a passion. At first glance, this appears libertarian and libertine, not puritanical. But while its devotion to open-ended sexual freedom stands diametrically opposite and opposed to radical Islamism, what they share is a realization of the political importance of sexuality and aspiration to political power that can be gained by controlling its terms and rules.

What one scholar calls 'sexualityism' has now positioned itself on the vanguard of left-wing politics (Alvare, 2012). Demands for 'power' and 'empowerment' indicate the emergence of more than a desire to be free of state interference and instead a true ideology, including clear aspirations to commandeer the state machinery. One sympathetic scholar terms it 'the ideology of the erotic' (Parker, 2009, p. 111). The older socialistic battle cry of 'social justice' is replaced with demands for 'erotic justice' (Correa, Petchesky\&Parker, 2008, pp. 4-5).

Like their predecessors, Western sexual radicals (and their opponents too) present their revolt primarily as the pursuit of sexual liberation. Yet, here too,

${ }^{12}$ Compare the words of one Puritan minister: 'When thou findest any lust of the flesh arising in thee, turn the strength of it into a spiritual end,' John Cotton urged. 'Art thou troubled with lust after women? ... Turn the strength of thy affection to another [purpose].' (Baskerville, 2018b, pp. 288-289) 
a corollary dimension of puritanism and even authoritarianism also appears. 'Having embraced the sexual revolution and encouraged an atmosphere of promiscuity,' Ken Masugi notes, the sexual left 'has now created a legalistic, centralised crackdown on talk about sex' (Masugi, 2013). This paradox has perplexed and fooled both liberal and conservative critics, who often support one side of the dialectic and reject the other. 'The old guard of feminists (rightly) battled against those who sought to constrain women within false and offensive notions of biological destiny,' writes one. 'But the new breed of gender warriors have pulled off the very opposite effect: a puritanical climate in which bodies are angrily policed and furiously weaponised, where an iron will to condemn and stamp out sexual waywardness wherever it is found... reigns supreme' (Strimpel, 2017). Likewise, two liberal former feminists seem sympathetic to freedom but uncomfortable with the authority. 'Feminists used to urge women to explore their own sexuality freely,' write Daphne Patai and Noretta Koertge, 'but now there is a figurative policing of the bedroom' (Patai\&Koertge, 1994, p. 3).

In some ways, the sexual revolutionaries have not discarded puritanism so much as they have changed its terms by redefining sexual sin. Traditional religious definitions have been replaced by secular definitions formulated in political language. Sexual indulgence is no longer a sin against God but now a crime against the state. Having ridiculed into silence traditional Christian morality, with its vocabulary of 'immorality,' 'licentiousness,' 'fornication,' and 'adultery,' the radicals substituted new crimes and expanded redefinitions of existing crimes, all involving sexuality - 'rape,' 'sexual assault,' 'sexual harassment,' 'sexual abuse,' 'sexual misconduct' (no clear distinctions separate these terms) - plus quasi-crimes of ideological heterodoxy: 'sexism,' 'misogyny,' 'homophobia' (Baskerville, 2017a; Gottschalk, 2006, pp. 115-116).

In effect, a new political theology carries a politicised definition of sin. The shame and stigma of the 'fornicator' and 'adulterer' have been replaced with that of the 'abuser' and 'harasser.' In the process, traditional morality is replaced with ideology and community pressure with criminal prosecution.

These two ideologies - Islamism and feminism-homosexualism - offer today's competing models for ordering the relations between the sexes, marriage, the family, and children. They also offer competing visions for the alignment of global power (Baskerville, 2018a). 


\section{THE ORIGINAL PURITANISM}

Yet a third model exists that also bases its legitimacy, in part, on its ability to manage the terms of sexuality and the family. This is the traditionally Christian West and the increasingly Christian global South (Jenkins, 2011). The West has also grappled in its past with not only sexual repression but also its political implications, and it has created its own religious and political radicalism. Indeed, it was the first to do so.

Here we return again to the origin of our own ideologies. For the obvious parallel is with our friends whom we have already introduced: the Cathars and Bogomils incipiently, but especially the Hussites and above all the Puritans, whose name is virtually synonymous with strict morality, including sexual morality. The Puritans were probably the world's most successful practitioners of the principle of repressing sexual freedom and harnessing sexual energy in the service of civic freedom (Baskerville, 2018b).

The popular understanding of 'Puritan' as abstinence from pleasure, including sexual pleasure, may indeed be that movement's most significant legacy (though ironically, now the one least fashionable among scholars). Campaigns against personal vice - not only sexual license, but swearing, drinking, gambling, blood sports, and other popular indulgences - involved more than 'the haunting fear that someone, somewhere may be happy,' in the words of H.L. Mencken. Decided political aims lay behind them: to create virtuous citizens. Puritanism might thus be seen as a massive program to implement what has since become the cliche that the price of freedom is eternal vigilance (Walzer, 1970). Like Lenin, the Puritans saw freedom as beyond the reach of people wallowing in indulgence and licentiousness. Self-government required self-control. 'There is a service which is freedom, the service of Christ; and there is a freedom which is servitude, freedom to sin,' one minister told the House of Commons during the English Revolution of the 1640s. 'There is a liberty which is bondage and...a bondage which is liberty' (Baskerville, 2018b, p. 196).

It is no accident that in their heyday the Puritans were also political revolutionaries - the world's first. They were certainly the Reformation's most sophisticated political activists. Their drive for personal purity was the launching point for larger campaigns demanding ecclesiastical purification, and from there to political reform.

Inseparable from their politics, the Puritans also produced early modern Europe's most voluminous literature on the family. This was hardly the quietest withdrawal from the public square into private life. On the contrary, 
the family was the Puritanism's institution for connecting sexuality and civic life, and the Puritans considered the family a 'little commonwealth,' whose members, especially children, were trained in the habits and techniques of citizenship and even political activism (Demos, 1970; Baskerville, 1993). Relevant here is that women were assigned essential responsibilities, and despite their reputation as purveyors of the 'patriarchal' family, the Puritans (paralleling later Islamism) attracted educated women in large numbers.

Puritanism is also renowned for promoting economic prosperity, supplying evidence for the 'Protestant ethic' thesis of sociologist Max Weber. Considering the family as the most basic unit of economic production, one consequence is almost certainly the material prosperity of the West. It was probably the Puritan commitment to family solidarity and integrity - as much or more than the predestinarian soteriology where Weber identified it - that served as the basis of the Protestant ethic of conscientious work leading to material affluence.

\section{THE DILEMMA OF EAST-CENTRAL EUROPE}

None of these ideological systems has had a major role in Central and Eastern Europe. As noted, Hussitism originated here, and its predecessors, pre-political forms of religious dissent such as the Bogomils were active in the Balkans. Islam was also a political presence, but imposed from outside in its pre-ideological form and not an indigenous Islamism.

And yet, like the ideologies of the last century, CEE is where they could clash, with global implications. The twentieth-century ideologies that wreaked such havoc here were imposed largely from outside, by major powers. Something similar may happen again, for CEE is again pivotal in global politics.

For one thing, changes in the Islamic world have put pressure on Europe, to which CEE countries have responded with the heightened defence of their national sovereignty. This has created tension between the European Union and Poland, Hungary, and others.

But the fault lines involve more than national sovereignty and nationalism, though that is how the Western media, ever-attentive to the battle lines in the 'previous war,' insists on simplifying it. A larger cultural and moral tension centres on the confrontation between traditional Christian faith and the new ideologies. 
Today's push back against western secularism is not primarily coming from Puritan northern Europe, though Puritan Britain and America are both involved. ${ }^{13}$ Rather, it is Catholic Central Europe and Orthodox Eastern Europe that are resisting. This is not a new Puritanism, for it is not ideological. The 'revolutions' it has already inspired were not theocratic but 'velvet.' Their aim was not to seize state power but to limit it.

But the push back does carry political implications. One major power is making a claim to leadership of this push back: Russia. This broadens the dynamic from culture to geopolitics, presenting a new East-West polarisation quite different from the old ones (Baskerville, 2017b). Though the old ideologies are effectively gone, we are left with a political polarity with a cultural (if not an 'ideological') subtext: Eastern Christian values versus Western secularism. Geographically and politically, it may be represented - eerily reminiscent of the past - in, respectively, Russia and a German-dominated EU. That Britain is pulling out of continental 'entanglements' and resuming its traditional role in 'splendid isolation' as offshore balancer-of-power is also uncanny.

This new polarity resembles past ones superficially, but now the ideological dimension is not social-economic or even nationalistic but religious-cultural (with sexual issues often accentuated). While CEE risks being (again) caught in the middle, the polarity also provides an opportunity to act as a pivot or broker between East and West. That a similar tension increasingly separates the West from the global South further augments this leverage, giving CEE importance above its size.

So CEE faces a choice: It can allow itself to again be a pawn in great power rivalries, or it can use its leverage to assert its own values against the hegemony, political or cultural, of both East and West. What those values are is not for me to say. But if Western institutions expand eastward and into the Balkans, the cultural gap between Western-sponsored elites and traditional populations could grow. Increased 'populism' will highlight pressures and contradictions within the NATO and EU alliances that may already stand in need of redefinition.

${ }^{13}$ Christian non-governmental organizations lobbying on family and sexual issues, though themselves usually rooted in Catholic and Orthodox churches, and clearly enjoying support from local populations, often follow the lead and adopt the techniques of (and may be funded by) the large American Evangelical law firm Alliance Defending Freedom, which has recently opened offices throughout Europe. 


\section{REFERENCES}

Altman, D. (2002). Global sex. Chicago, University of Chicago Press.

Alvare, H. (2012, July 16). 'The White House and Sexualityism,' Public Discourse, retrieved from http://www.thepublicdiscourse.com/ 2012/07/5757/. Accessed 30 January 2021.

Baskerville, S. (2018a). The sexual jihad. New Male Studies, 7(1).

Baskerville, S. (2018b). Not peace but a sword. London, Routledge, 1993; expanded edition Wipf and Stock.

Baskerville, S. (2017a). The new politics of sex. Kettering, Ohio, Angelico.

Baskerville, S. (2017b) 'The Devil Comes from the West': Russian Religious Politics and Central Europe, unpublished paper, https://www. academia.edu/35625622/_The_Devil_Comes_from_the_West_Russian_ Religious_Politics_and_Central_Europe.

Baskerville, S. (2004). Hussites, Puritans, and the politics of religious revolutions, Communio viatorum, 46(2).

Baskerville, S. (1993). The family in Puritan political theology, Journal of Family History, 18(2).

Buruma, B.\&Margalit A. (2004). Occidentalism. New York, Penguin.

Cavanaugh, W. (2009). The myth of religious violence. Oxford: Oxford University Press.

Charnock, S. (1840). Discourses upon the existence and attributes of God. London, Thomas Tegg.

Cohn, N. (1970). The Pursuit of the Millennium. Oxford, Oxford University Press.

Corrêa, S., Petchesky R.\&Parker R. (2008). Sexuality, health, and human rights. Abingdon, Routledge.

Lutzow, F. (1909). The life and times of Master John Hus. London, E.P. Dutton.

Demos, J. (1970). A little commonwealth. Oxford, Oxford University Press.

Djilas, M. (1958). The new class. New York, Praeger.

D'Souza, D. (2007). The enemy at home. New York, Doubleday.

Eley, G. (2002). Forging democracy. Oxford, Oxford University Press.

Gottschalk, M. (2006). The prison and the gallows. Cambridge, Cambridge University Press.

Halliday, F. (2011). The vagaries of 'anti-imperialism,' in: Political Journeys. London, Saqi. 
Hansen, H.\&Kainz P., Radical Islamism and totalitarian ideology: A comparison of Sayyid Qutb's Islamism with Marxism and National Socialism," Totalitarian Movements and Political Religions, 8(1), pp. 55-76.

Hymowitz, K. (2003, Winter). Why feminism is AWOL on Islam.' City Journal.

Jenkins, P. (2011). The Next Christendom. Oxford, Oxford University Press.

Juergensmeyer, M., Kitts M.,\&Jerryson M. (Eds.) (2013). The Oxford handbook of religion and violence. New York, Oxford University Press.

Juergensmeyer, M.\&Kitts M. (Eds.) (2011). Princeton readings in religion and violence. Princeton, Princeton University Press.

Kazemzadeh, M. (2002). Islamic fundamentalism, feminism, and gender inequality in Iran under Khomeini. Lanham, Md., University Press of America.

Lukacs, J. (2009). Last Rights. New Haven, Yale University Press.

Mackinder, H. (1904), The Geographical Pivot of History, The Geographical Journal, 23(4), pp. 421-437.

Masugi, K. (2013, May 16). The De-Eroticized University, retrieved from http:/ / www.libertylawsite.org/2013/05/16/the-de-eroticizeduniversity/. Accessed 30 January 2021.

Moghissi, M. (2004). Women and Islam. London, Routledge.

Parker, R. (2009). Bodies, pleasures, and passions. Nashville, Vanderbilt University Press.

Patai D.\&Koertge N. (1994). Professing feminism. New York, Basic Books.

Rachik, K. (2009). How religion turns into ideology, Journal of African Studies, 14(3-4), pp. 347-358.

Roded, R. (1999). Women in Islam and the Middle East. London, I.B.Tauris.

Roy, R. (1998). Failure of political Islam. Cambridge, Mass., Harvard University Press.

'The Russian Effort to Abolish Marriage,' by 'a woman resident in Russia' (1926, July 1). Atlantic Monthly, retrieved from http:/ / www.theatlantic. com/magazine/archive/1926/07/the-russian-effort-to-abolishmarriage/306295/. Accessed 30 January 2021.

Strimpel, Z. (2017, November 9). The Long March of the left has made the human body sinful again. Daily Telegraph, retrieved from https:// www.telegraph.co.uk. Accessed 9 December 2020. 
Tismaneanu's, V. (2014). The Devil in history. Berkeley, University of California Press.

Ulph, S. (2012). Islam and totalitarianism: The challenge of comparison, in: K. Gorka\&Sookhdeo P.(Eds.), Fighting the Ideological War. McLean, Virginia, Isaac.

Voegelin, E. (1998). The history of political ideas, vol. 6, Revolution and the New Science, in: B. Cooper (Ed.), The collected works of Eric Voegelin, (pp. 131214). Columbia, University of Missouri Press.

Walzer, M. (2015). The paradox of liberation. New Haven, Yale University Press.

Walzer, M. (1970). The revolutionary uses of repression, in: M. Richter (Ed.), Essays in theory and history. Cambridge, Mass., Harvard University Press.

Walzer, M. (1965). The revolution of the saints. Cambridge, Mass., Harvard University Press.

Zetkin, C. (1934). Reminiscences of Lenin. Marxists' Internet Archive, 2012, https:// www.marxists.org/archive/zetkin/1924/reminiscences-oflenin.htm).

Ziemke, C. (2000). The national myth and strategic personality of Iran, in: V.A. Utgoff (Ed.), The coming crisis. Cambridge, Mass., Belfer Center for Science and International Affairs. 